\title{
Price Discovery in Indian Agricultural Commodity Markets
}

\author{
Prof. Sanjay Sehgal \\ Professor of Finance, Department of Financial Studies \\ University of Delhi, South Campus \\ Dr. Namita Rajput (Corresponding author) \\ Associate Professor, Department of Commerce \\ University of Delhi, Sri Aurobindo College (M) \\ Email: namitarajput27@gmail.com \\ Rajeev Kumar Dua \\ Research Scholar \\ University, CMJ Shilong, Meghalaya
}

Received: July 13, 2012 Accepted: August 07, 2012 DOI: 10.5296/ijafr.v2i2.2224

\begin{abstract}
In this paper, the price discovery relationship for ten agricultural commodities has been examined. Price discovery is confirmed for all commodities except Turmeric. Price discovery results are encouraging given the nascent character of commodity market in India. However the market does not seem to be competitive. The findings have implications for policy makers, hedgers and investors and will help in deeply understanding the role of futures market in information dissemination. The commodity exchanges must strengthen their surveillance system for early detection on continuous basis of anomalous trading behaviour. These markets are becoming informational mature and market regulators have taken adequate steps for market development. Forwards Market Commission (FMC) should be given adequate powers to regulate commodity market and penalise any insider trading and price manipulations. Well-organized spot markets must be developed, ensuring transparency and trading efficiency. Electronically traded spot exchanges must be developed and warehousing; testing labs as well as other eco-system linkages must be established to strengthen the derivative market trading
\end{abstract}


mechanism for efficient price discovery mechanism.

JEL: G13; G14; G 15; G18; C32

Keywords: Price discovery, Granger Causality, Volatility, Spillover, Emerging markets.

\section{Introduction}

Commodities are considered as separate asset class. To obtain economic exposure to commodity asset, commodity derivatives is a very useful tool. There are many instruments traded in these markets which include financial instruments such as futures and forward contracts, options, swaps, and physical instruments like inventories. Future contracts are among the most important of these instruments, and provide significant information about cash and storage markets. Price discovery, hedging, financing, liquidity, price stabilization, encouraging competition, increasing efficiency, inherent leverage, low transaction costs, and lack of short sale restrictions as well as fulfilling desires of speculators are some of the prime economic functions of the futures market as suggested by( Fleming, Ostdiek and Whaley, 1996). As a result, prices are first updated in the futures market, which thus serves as a price discovery vehicle for investors Tse, (1999). There are other explanations also for one market leading the other infrequent trading hypothesis of Tan and Lim, (2001); liquidity factor identified by Daigler, (1990,) etc. From an empirical outlook, a considerable scholastic and expert literature explores the dynamics of stock index and index futures prices in developed economies with the aim of determining dominant role is of which market. The methodologies of these studies vary widely, but the major finding is that the dominant influence runs from the futures market to the cash and weaker effects (though still measurable) occur in the reverse direction (Joel, 2003). Chan (1992), using intra-day data, reports a strong evidence to show that there is a dominant role of futures market and weak evidence that the cash index leads the futures market. He concludes that the futures market is the main source of market-wide information and there is a price discovery in the futures market.

\subsection{Relationship between Futures and Spot Markets}

The issue of the lead-lag relationship, price discovery in returns and volatility spillover has been researched extensively in developed countries equity, currency and commodity markets. In equity markets, there are numerous studies which explain the return and volatility spillovers between spot and futures markets. Of late, studies in this area use high frequency (intraday) data to understand the relationship more precisely. Some of the important studies include the work of Gardbade and Silber (1983), Herbst, McCormack and West (1987), Kawaller et al. (1987), Stoll and Whaley (1990), Cheung and Ng (1990), Chan, Chan, and Karolyi (1991), Schroeder and Goodwin (1991), Chan (1992), Chang et al.(1995), Antoniou and Garrett (1993), Abhyankar (1998), Antoniou et al. (2001),Brooks et al. (2001), Hodgson, Masih, and Masih (2006), Floros and Vougas (2007), and Kavussanos, Visvikis and Alexakis (2008).In the studies mentioned above dominant role of futures was found.

Price discovery and risk transfer are considered to be two major contributions of futures market towards the organization of economic activity (Garbade and Silber, 1983). Price discovery refers to the use of future prices for pricing cash market transactions. This implies that futures price serves as market's expectations of subsequent spot price. Understanding the 


\section{Mll Macrothink}

International Journal of Accounting and Financial Reporting ISSN 2162-3082 2012, Vol. 2, No. 2

influence of one market on the other and the role of each market segment in price discovery is the central question in market microstructure design and is very important to academia and regulators. In efficient markets, new information is impounded simultaneously into cash and futures markets (Zhong et al. 2004). In other words, financial market pricing theory states that market efficiency is a function of how fast and how much information is reflected in prices. The rate at which prices exhibit market information is the rate at which this information is disseminated to market participants (Zapata et al. 2005). In reality, institutional factors such as liquidity, transaction costs, and other market restrictions may produce an empirical lead-lag relationship between price changes in the two markets. Moreover, all the markets do not trade simultaneously for many assets and commodities. Besides being of academic interest, understanding information flow across markets is important for portfolio managers and hedgers for hedging and devising cross-market investment strategies. The market that provides the greater liquidity and low trading cost as advocated by Fleming, Ostdiek and Whaley (1996) is likely to play a more important role in price discovery. Therefore, it has become necessary, from time to time, to conduct empirical studies to measure the impact of financial derivatives, in our case commodity futures of agricultural commodities, on price discovery to spot market and vice-versa.

Commodity derivatives made their appearance before financial derivatives in the world and also in India. Informal trading in commodity derivatives was there even in ancient India, but the formal market took shape in the late nineteenth century. However, the growth path of the Indian derivative market was not smooth. Commodity futures' trading has existed in India since 1875. However, the commodity futures have been in the state of hibernation for the past few decades owing to a lot of government restrictions. Significant developments took place in 2003-04 related to commodity futures market in terms of revoking prohibition on non-transferable specific delivery forward contracts. Commodity derivatives have a significant role in the price risk management process especially in case of India being an agricultural dominated economy. India is one of the top producers of commodities, $5^{\text {th }}$ largest in the world, engages $57 \%$ of the world population and contributes $22 \%$ to the GDP of the country. It is also the largest consumers having a large population base and hence India should take a leadership role at international level. This indicates that India can be promoted as a major centre for trading of commodities derivatives market. The commodity derivatives trading have ecosystem linkages which results in employment generation process. The developments in the Indian market in the past decade has led the Indian commodity exchanges to be at par with the world markets with setting up of national exchanges and modern institutions in term of warehousing facilities and clearing have led to reduction in price distortions.

The futures market was opened in anticipation of sound institutional framework and market design. At present there are five national and sixteen regional commodity exchanges operating in India. The total volume of trade in the commodity future market rose from Rs.20.53 trillion in 2005-06 to Rs.112.52 trillion in 2010-11. As in 2012, the number of commodities eligible for futures trading is 113 on 21 recognized exchanges. A number of committees have been constituted to inspect, control, and standardize this market at numerous occasions at the behest of government of India, namely, A.D. Shroff Committee 
(1950), M. L. Dantwala Committee (1966), A.M. Khusro Committee (1979), K.N. Kabra Committee (1993), Shankarlal Guru Committee (2001), Habibullah Committee (2003), and lastly Sen Committee (2008). More or less, those committees "recommendations, inevitably, stand out few indicatives with respect to measuring the efficiency of Indian commodity futures markets, contentions at the back of low extent of participation or on the contrary, unwarranted speculation, and inference behind impositions of ban on several commodities telling to their economic fundamentals and trade-policies (FTGKMC, 2011).

The characteristics of emerging markets are very different from that of developed markets. According to Bakaert and Harvey (1997) and Antoniou and Ergul (1997), emerging markets are characterized by low liquidity, thin trading volume, higher sample average returns, low correlation with developed market returns, non-normality, better predictability, higher volatility of returns, and small-size sample availability. It is usual to assume that the emerging futures markets exhibit higher price variability and poor information processing capabilities (Tomek, 1980; Carter, 1989).

Issue of price discovery have been extensively researched for mature markets with greater focus on equity markets. The work is very limited for commodity markets in emerging markets in general and India in particular. A commodity future trading has played an important role in economic development because of its eco-system linkages and role in employment generation. These trading platforms have also helped in integrating Indian markets with the world markets, thus, reducing any price distortions. Since India is one of the largest consumer as well as producer of many agri commodities, time is ripe for India to take a dominant role in price leadership at international level. In this backdrop, it is important to empirically examine the price discovery mechanism of select agri-commodities. Poor flow of information may consequently affect the price discovery process in such markets. New commodity futures markets in developing economies like India usually have thin volumes and low market depth, lack of well developed spot markets, poor delivery systems, policy restrictions and taxes on the movement of commodities, and other market imperfections. Given these differences, it is important to investigate empirically the Indian commodity futures markets more extensively so as to shed light on the role played by the futures markets in the price discovery process. We specially focus on ten agricultural commodities, i.e. Chana, guar seeds, soya bean, Kapas, Potato Agra, Turmeric, Black Pepper, Barley, Maize and Castor seeds.

In this backdrop, an attempt has been made to revisit the debate on price discovery in Indian commodities market. It covers fairly longer study period compared to prior research of the subject. The study attempts to address the following question:

Is futures prices are useful in price discovery mechanism of spot prices?

The remainder of the paper is organized as follows. Section two gives review of literature and the relevance of study. Section three contains description of data and the methodology employed along with the empirical tests carried out. Section IV exhibits analysis and interpretation of the data through a variety of tables into which relevant details have been compressed and summarized under appropriate heads and presented in the tables. Section V provides brief summary, conclusion of the main findings, policy implications, limitations of 
the study and directions for future research.

\section{Review of Literature}

There are numerous studies that have been explored in the ascertainment of whether the price information is reflected in the spot market or in its underlying futures market under various interval of time since the introduction of futures in Indian commodity market. Derivatives trading in the commodity market have been a topic of enthusiasm of research in the field of finance. There have been contrary views on impact of derivatives trading. A number of studies have been done to study the impact of introduction of future trading in commodity markets on the price volatility. There have been two sets of findings, one stating that introduction of derivatives in stock market has increased the volatility and market performance and other stating that introduction of derivatives has reduced the volatility in stock marker thereby increasing its stability. This study adds to the existing literature in this field using some of the econometric tools like Co-integration, VECM models and Block Exogeneity Test (Causality Test) to bring conclusiveness to the subject.

Garbage and Silber (1983) use simultaneous price dynamics to model spot and future prices, in which changes in spot and futures prices on $\mathrm{t}$ are a function of the basis on $\mathrm{t}-1$, this model has been extended on four storable agricultural commodities to examine the characteristics of spot and future characteristics. They suggested that price discovery role of future market might be affected by liquidity and market size. Edwards (1988a \& 1988b) study the spot price volatility before and after the introduction of futures and find that futures may induce price volatility in the short run but this volatility did not appear in the long run. Koontz et al. (1990) investigate the spatial price discovery mechanism in the livestock market and found that there was high degree of interaction between cash and futures prices using Geweke's causality test (1982). They also find that the price discovery process is dynamic and the structure of the market influences it. Thomas and Karande (2001) analyze price discovery in India's castor seed market and show that markets that trade exactly the same asset in the same time zone, do react differently to information and also small market may lead the large market. Moosa (2002) with the objective to find out if crude oil performs the function of price discovery and risk transfer re-examine the Garbade and Silber (1983) model. With the daily data he finds that sixty percent of the price discovery function is performed by the futures. It is also discovered in the results that there is a fairly elastic supply of arbitrage system and that Garbade and Silber model is more suitable for intraday behaviour of spot and future prices.

Kumar and Sunil (2004) examine the price discovery for five commoditiies in six Indian commodities exchanges. Daily futures and comparable ready prices have been used in the study and the ratio of standard deviations of spot and future rates have been taken for empirical testing of ability of futures markets to incorporate information well. Besides, the study empirically analyzes the efficiency of spot and future markets by employing the Johansen cointegration technique. They find the inability of future market to fully incorporate information and confirmed inefficiency of future market. However, the authors conclude that the Indian agricultural commodities future markets are not yet mature and efficient. The study by Zapata, Fortenbery and Armstrong (2005) examine the observations taken from January 1990 to January 1995 of 11 future prices traded in New York and the World cash prices for exported sugar. They report that future market for sugar leads the cash market in price 
discovery. A unidirectional causality from future price to spot is revealed in the study. Futures and cash prices are found to be co-integrated which suggests that sugar future contract is a useful vehicle for reducing overall market price risk faced by cash market participants selling at the world price. In a study conducted by Silvapulle and Moosa (1999) and Karande (2006) a lead is found in the futures prices implying that price is being discovered first in that market and latter in spot market. It is found that the futures prices play a dominant role and the future prices of crude oil and castor seed lead spot prices. Primarily why a lead-lag relationship between the two markets is observed is that it is less costly since transaction cost is lower and the degree of leverage attainable is higher.

Fu and Qing (2006) study the price discovery process and volatility spillovers in Chinese spot-futures markets through Johansen co-integration, VECM and bivariate EGARCH model. It is indicated in the results that there is a long-term equilibrium relationship and significant bidirectional information flows between spot and futures markets in China, with a dominant role played by futures market. Although innovations in one market could predict the futures volatility in another market, the volatility spillovers from futures to spot are more significant than the other way round. Dash, Andrews (2010) examine the market behavior and causality effects between spot and futures prices in Indian commodity markets. The pattern is quite different for different commodities. Commodities that suffer from chronic backwardation must be analyzed in more detail, in order to understand the causes, and controls (known as backwardation limits) should be instituted for the same. Causality in commodities markets can be used to either hedge or speculate price movements: if changes in spot prices drive changes in futures prices, efficient hedging strategies can be formulated; whereas if changes in futures prices impel change in spot prices, efficient speculation strategies can be developed. Further, causality can be used in forecasting commodity spot and futures prices.

As mentioned above, empirical literature on price discovery mainly deals with developed markets like US and UK. In India significant and relevant literature on commodity market is thin and has mainly focussed on agricultural commodities (Kabra, (2007; Kolamkar, (2003); Kumar and Pandey, (2009); Naik and Jain, (2002); Ramaswami and Singh, (2007); Raipuria, (2002); Roy, (2008); Sabnavis and Jain, 2007; Thomas, 2003; Nair, 2004, Ghosh (2009a), (2009b), (2010a), Pavaskar (2009) and Pavaskar and Ghosh (2009), Dey, (2009); Dey and Maitra, (2011)).

Further the Indian literature is limited to regional exchanges, dated/small sample form the period prior to setting up of national exchanges, or to very fewer commodities traded on national exchanges (Thomas and Karande, 2001; Naik and Jain, 2002; Roy, 2008; and Roy and Dey, 2009). This paper examines the case for India i.e., the futures market effectively serves the price discovery function in case of Agricultural commodities like Chana, Guar Seeds, Soya Bean, Kapas, Potato Agra, Turmeric, Black Pepper, Barley, Maize and Castor Seeds. 


\section{Data and Methodology}

The sample used in the study consists of ten agricultural commodities traded on National Commodity Exchange of India, Mumbai. i.e. Chana, Guar Seeds, Soya Bean, Kapas, Potato Agra, Turmeric, Black Pepper, Barley, Maize and Castor Seeds.

The period of study is from November 2003-to March 2012; however data period varies across commodities owing to their late introduction on trading exchanges and the fact that some agricultural commodities were banned from trading for a certain period to curb speculative impacts which according to policy makers could have triggered high inflation. The data comprises of daily closing spot and futures prices of the sample commodities. Natural logarithm of daily prices is taken to minimize the heteroscedasticity in data. The list of sample commodities as well as their data period is given in the following Table 1.

\section{Table 1: Name of Sample Agricultural Commodities}

\begin{tabular}{|c|c|c|}
\hline AGRI COMMODITIES & Data-Periods & Future Market \\
\hline CHANA & $13-04-2004$ to 31-03-2012 & NCDEX \\
\hline GUARSEED & $13-04-2004$ to 31-03-2012 & NCDEX \\
\hline SOYBEAN & $01-09-2004$ to 31-03-2012 & NCDEX \\
\hline KAPAS & $01-04-2004$ to 31-03-2012 & NCDEX \\
\hline POTATO AGRA & $05-07-2006$ to 31-03-2012 & NCDEX \\
\hline TURMERIC, & $13-04-2004$ to 31-03-2012 & NCDEX \\
\hline BLACK-PEPPER & $13-04-2004$ to 31-03-2012 & NCDEX \\
\hline BARLEY & $13-04-2004$ to 31-03-2012 & NCDEX \\
\hline MAIZE & $01-5-2005$ to 31-03-2012 & NCDEX \\
\hline CASTOR SEED & $21-9-2004$ to 31-03-2012 & NCDEX \\
\hline
\end{tabular}

The table shows the sample commodity and indices used in the study. The period of study is from November 2003-to March 2012 however the data period varies across commodities. The sample consists of ten agricultural commodities comprising of Metal, Energy and agricultural commodities.

Given the nature of the problem and the quantum of data and to establish in detail price discovery mechanism we perform necessary test. The regression analysis would yield efficient and time invariant estimates provided that the variables are stationary over time. However, many financial and macroeconomic time series behave like random walk. We first test whether or not the spot and futures price series are co-integrated. The concept of co-integration becomes relevant when the time series being analyzed are non stationary. The time series stationarity of sample price series has been tested using Augmented Dickey Fuller (ADF) 1981. The ADF test uses the existence of a unit root as the null hypothesis. To double check the robustness of the results, Phillips and Perron (1988) test of stationarity has also 
been performed for the series, after confirming the co- integrating vector which confirms causality in one direction we perform block Exogeneity test which describes the direction of causality which is exhibited in detail in results section.

\section{Analysis and Interpretations of Results}

The results of stationarity tests are given in Table 2. It confirms non stationarity of commodity price data; hence we repeat stationarity tests on return series (estimated as first difference of log prices) which are also provided in Table 2. The table describes the sample price series that have been tested using Augmented Dickey Fuller (ADF) 1981. The ADF test uses the existence of a unit root as the null hypothesis. To double check the robustness of the results, Phillips and Perron (1988) test of stationarity has also been performed for the price series and then both the test are performed on return series. Panel A (Price Series)and Panel B (Return Series) report results of and commodities respectively. The sample return series exhibit stationarity thus conforming that both spot and future commodity prices are integrated to the first order.

Table 2: Stationarity Test for Sample Commodities

\begin{tabular}{|c|c|c|c|c|}
\hline & \multicolumn{2}{|c|}{ Panel-APrice- Series } & \multicolumn{2}{|c|}{ Panel-B Inference On Return Series Integration I (I) } \\
\hline & ADF Test & Phillips-Perron Test & ADF Test & Phillips-Perron Test \\
\hline & t-statistics & t-statistics & t-statistics & t-statistics \\
\hline \multicolumn{5}{|l|}{ CHANA } \\
\hline (A)FUTURE PRICES & -2.42 & -2.46 & $-40.85 * *$ & $-40.82 * *$ \\
\hline (B) SPOT PRICES & -2.41 & -2.32 & $-40.62 * *$ & $-40.62 * *$ \\
\hline \multicolumn{5}{|l|}{ GUARSEED } \\
\hline (A) FUTURE-PRICE & -2.19 & -2.17 & $-36.5 * *$ & $-36.51 * *$ \\
\hline (B)SPOT-PRICE & -1.1 & -1.3 & $-24.9 * *$ & $-42.18 * *$ \\
\hline \multicolumn{5}{|l|}{ SOYBEAN } \\
\hline (A)FUTURE-PRICE & -1.17 & 0.096 & $-44.07 * *$ & $-44.17 * *$ \\
\hline (B)SPOT-PRICE & -0.1 & 0.44 & $-44.08 * *$ & $-44.09 * *$ \\
\hline \multicolumn{5}{|l|}{ KAPAS } \\
\hline (A)FUTURE-PRICE & 0.81 & 0.69 & $-34.95 * *$ & $-34.95 * *$ \\
\hline (B)SPOT-PRICE & -0.1 & -0.16 & $-36.44 * *$ & $-36.45 * *$ \\
\hline \multicolumn{5}{|l|}{ POTATO AGRA } \\
\hline (A)FUTURE-PRICE & -2.67 & -2.67 & $-36.33 * *$ & $-36.33 * *$ \\
\hline
\end{tabular}




\begin{tabular}{|c|c|c|c|c|}
\hline (B)SPOT-PRICE & 1.85 & 3.09 & $-8.36 * *$ & $-36.84 * *$ \\
\hline \multicolumn{5}{|l|}{ TURMERIC } \\
\hline (A)FUTURE-PRICE & -2.19 & -2.17 & $-36.5 * *$ & $-36.51 * *$ \\
\hline (B)SPOT-PRICE & -1.1 & -1.3 & $-24.9 * *$ & $-42.18 * *$ \\
\hline \multicolumn{5}{|l|}{ BLACK PEPPER } \\
\hline (A)FUTURE-PRICE & -0.57 & -0.53 & $-26.75 * *$ & $-26.74 * *$ \\
\hline (B)SPOT-PRICE & -0.42 & -0.42 & $-27.76 * *$ & $-27.71 * *$ \\
\hline \multicolumn{5}{|l|}{ BARLEY } \\
\hline (A)FUTURE-PRICE & 0.81 & 0.69 & $-34.95 * *$ & $-34.95 * *$ \\
\hline (B)SPOT-PRICE & -0.1 & -0.16 & $-36.44 * *$ & $-36.45 * *$ \\
\hline \multicolumn{5}{|l|}{ MAIZE } \\
\hline (A)FUTURE-PRICE & -2.67 & -2.67 & $-36.33 * *$ & $-36.33 * *$ \\
\hline (B)SPOT-PRICE & 1.85 & 3.09 & $-8.36 * *$ & $-36.84 * *$ \\
\hline \multicolumn{5}{|l|}{ CASTOR SEED } \\
\hline (A)FUTURE-PRICE & 0.36 & 0.4 & $-42.47 * *$ & $-42.47 * *$ \\
\hline (B)SPOT-PRICE & -0.35 & -0.32 & $-43.76 * *$ & $-43.76 * *$ \\
\hline
\end{tabular}

The table describes the sample price series that have been tested using Augmented Dickey Fuller (ADF) 1981. The ADF test uses the existence of a unit root as the null hypothesis. To double check the robustness of the results, Phillips and Perron (1988) test of stationarity has also been performed for the price series and then both the test are performed on return series also as shown in Panel-A (price series) and Panel B (Return series) are integrated to I(1). All tests are performed using 5\%level of significance (**).

If two or more series are themselves non-stationary, but a linear combination of them is stationary, then the series is said to be co-integrated. Given that each commodity spot and futures prices are integrated of the same order, co-integration techniques are used to determine the existence of a stable long-run relationship between the price pairs. Arrival of new information results in price discovery for short intervals of time between futures and spot market due to communication cost. Increased availability and lower cost of information account together for faster assimilation of information in the futures market than a spot market (Koontz et al., 1990). The price linkage between futures market and spot market is examined using cointegration (Johansen, 1991) analysis that has several advantages. First, 
cointegration analysis reveals the extent to which two markets have moved together towards long run equilibrium. Secondly, it allows for divergence of respective markets from long-run equilibrium in the short run. The co -integrating vector identify the existence of long run equilibrium while error correction dynamics describes the price discovery process that helps the markets to achieve equilibrium (Schreiber and Schwartz, 1986). Co-integrating methodology fundamentally proceeds with non-stationary nature of level series and minimizes the discrepancy that arises from the deviation of long-run equilibrium. The observed deviations from long-run equilibrium are not only guided by the stochastic process and random shocks in the system but also by other forces like arbitrage process. As a result, the process of arbitrage possesses dominant power in the commodity future market to minimize the very likelihood of the short run disequilibrium. Moreover, it is theoretically claimed that if futures and spot price are coinetgrated, then it implies presence of causality at least in one direction. On the other hand, if some level series are integrated of the same order, it does not mean that both level series are coinetgrated. Cointegration implies linear combinations of both level series cancelling the stochastic trend, thereby producing a stationary series. Johansen's cointegration test is more sensitive to the lag length employed. Besides, inappropriate lag length may give rise to problems of either over parameterization or underparametrisation. The objective of the estimation is to ensure that there is no serial correlation in the residuals. Here, Akaike information criterion (AIC) is used to select the optimal lag length and all related calculations have been done embedding that lag length. The cointegration results are reported in Table 3.

Table 3: Johansen's Co-Integration Test

\begin{tabular}{|c|c|c|c|c|}
\hline & Lag Length & Max Eigen Value & Trace Statistic & Critical Value** \\
\hline \multicolumn{5}{|l|}{ Panel A: INDICES } \\
\hline \multicolumn{5}{|l|}{ CHANA } \\
\hline (A)FUTURE PRICES & 2 lags* & 177 & 181.65 & 15.49 \\
\hline (B) SPOT PRICES & & 4.64 & 4.64 & 3.84 \\
\hline \multicolumn{5}{|l|}{ GUARSEED } \\
\hline (A) FUTURE-PRICE & 2 lags* & 337.06 & 339.86 & 15.49 \\
\hline (B)SPOT-PRICE & & 2.8 & 2.8 & 3.84 \\
\hline \multicolumn{5}{|l|}{ SOYBEAN } \\
\hline (A)FUTURE-PRICE & 2 lags* & 27.86 & 28.67 & 15.49 \\
\hline (B)SPOT-PRICE & & 0.81 & 0.81 & 3.84 \\
\hline \multicolumn{5}{|l|}{ KAPAS } \\
\hline (A)FUTURE-PRICE & 3 lags* & 77.99 & 82.58 & 15.49 \\
\hline
\end{tabular}




\begin{tabular}{|c|c|c|c|c|}
\hline (B)SPOT-PRICE & & 4.59 & 4.59 & 3.84 \\
\hline \multicolumn{5}{|l|}{ POTATO AGRA } \\
\hline (A)FUTURE-PRICE & 3 lags* & 57.59 & 62.41 & 15.49 \\
\hline (B)SPOT-PRICE & & 4.82 & 4.82 & 3.84 \\
\hline \multicolumn{5}{|l|}{ TURMERIC } \\
\hline (A)FUTURE-PRICE & 3 lags* & 11.76 & 12 & 15.49 \\
\hline (B)SPOT-PRICE & & 0.24 & 0.24 & 3.84 \\
\hline \multicolumn{5}{|l|}{ BLACK PEPPER } \\
\hline (A)FUTURE-PRICE & 2 lags* & 77.54 & 77.69 & 15.49 \\
\hline (B)SPOT-PRICE & & 0.14 & 0.14 & 3.84 \\
\hline \multicolumn{5}{|l|}{ BARLEY } \\
\hline (A)FUTURE-PRICE & 3 lags* & 300.6 & 302.56 & 15.49 \\
\hline (B)SPOT-PRICE & & 1.961 & 1.96 & 3.84 \\
\hline \multicolumn{5}{|l|}{ MAIZE } \\
\hline (A)FUTURE-PRICE & 3 lags* & 65.13 & 69.66 & 15.49 \\
\hline (B)SPOT-PRICE & & 4.52 & 4.52 & 3.84 \\
\hline \multicolumn{5}{|l|}{ CASTORSEED } \\
\hline (A)FUTURE-PRICE & 2 lags* & 9.65 & 9.66 & 15.49 \\
\hline (B)SPOT-PRICE & & $\mathbf{0}$ & $\mathbf{0}$ & 3.84 \\
\hline
\end{tabular}

The table provides the Johansen's co-integration test, maximal Eigen value and Trace test statistics are used to interpret whether null hypothesis of $r=0$ is rejected at $5 \%$ level and not rejected where $r=1$. Rejection of null hypothesis implies that there exists at least one co-integrating vector which confirms a long run equilibrium relationship between the two variables, spot and future prices in our case. The null hypothesis is rejected in 9 commodities except Turmeric, which reveals that one cointegration relationship exists between spot and futures prices.

Maximal Eigen value and trace test statistics are used to interpret whether null hypothesis of $\mathrm{r}$ $=0$ is rejected at $5 \%$ level and not rejected when $r=1$. Rejection of null hypothesis implies 


\section{Mll Macrothink}

International Journal of Accounting and Financial Reporting

ISSN 2162-3082

2012, Vol. 2, No. 2

that there exists at least one co-integrating vector which confirms a long run equilibrium relationship between the two variables, spot and future prices in our case. The null hypothesis is rejected in case of 9 out of 10 commodities (Chana, Guarseed, Soybean, Kapas, Potato Agra, Black pepper, Barley, Maize and castor seed), with an exception of Turmeric, Which reveals that one cointegration relationship exists between spot and futures prices. Thus, spot and futures prices of these agricultural commodities share common long-run information. Our cointegration result confirm that in general there is a price discovery process in the spot and future commodity markets .Moreover, cointegration analysis delivers the message saying how two markets (such as futures and spot commodity markets) reveal pricing information that are identified through the price difference between the respective markets. The implication of cointegration is that the commodities in two separate markets respond disproportionately to the pricing information in the short run, but they converge to equilibrium in the long run under the condition that both markets are innovative and efficient. In other words, the root cause of disproportionate response to the market information is that a particular market is not dynamic in terms of accessing the new flow of information and adopting better technology. Therefore, there is a consensus that price change in one market (futures or spot commodity market) generates price change in the other market (spot or commodity futures) with a view to bring a long run equilibrium relation is :

$$
F_{t}=\alpha+\beta S_{t}+\varepsilon_{t}
$$

Equation (1) can be expressed as in the residual form as: ệ

$$
F_{t} \quad S_{t}=\text { ệ t }
$$

In the above equations $F_{t}$ and $S_{t}$ are futures and spot prices of a commodity in the respective market at time t. Both $\alpha$ and $\beta$ are intercept and coefficient terms, where as $\hat{e}_{t}$ is estimated white noise disturbance term. The main advantage of cointegration is that each series can be represented by an error correction model which includes last period's equilibrium error with adding intercept term as well as lagged values of first difference of each variable. Therefore, casual relationship can be gauged by examining the statistical significance. In addition, the empirical results of the Granger causality test find the short run lead-lag relationship between futures and spot prices. It tests whether one variable is significantly explained by the other variable. More specifically, we say that futures returns Granger cause spot returns if some of the coefficients of lagged futures returns are nonzero and/or the error correcting term is significant at conventional levels. Similarly, spot returns Granger cause futures returns if some of the coefficients of lagged spot returns are nonzero and/or the error correcting term is significant at conventional levels. The results of Granger causality tests are reported in Table 4 
Table 4 : The Empirical Results of Variance decomposition analysis and Granger Lead Analysis

\begin{tabular}{|c|c|c|c|c|c|c|c|}
\hline \multicolumn{8}{|c|}{ GRANGER CAUSALITY TESTS } \\
\hline \multicolumn{2}{|c|}{ GUARSEED } & \multicolumn{2}{|c|}{ TURMERIC } & \multicolumn{2}{|l|}{ SOYBEAN } & \multicolumn{2}{|c|}{ BLACK PEPPER } \\
\hline $\begin{array}{l}\text { DV: } \\
\text { future } \\
\text { price }\end{array}$ & $\begin{array}{l}\text { DV: spot } \\
\text { price }\end{array}$ & $\begin{array}{l}\text { DV: } \\
\text { spot } \\
\text { price }\end{array}$ & $\begin{array}{l}\text { DV: spot } \\
\text { price }\end{array}$ & $\begin{array}{l}\text { DV: future } \\
\text { price }\end{array}$ & $\begin{array}{l}\text { DV: spot } \\
\text { price }\end{array}$ & $\begin{array}{l}\text { DV: future } \\
\text { price }\end{array}$ & $\begin{array}{l}\text { DV: spot } \\
\text { price }\end{array}$ \\
\hline $\mathrm{P}(0.00)$ & $\mathrm{P}(0.00)$ & $\mathrm{P}(0.80)$ & $\mathrm{P}(0.70)$ & $\mathrm{P}(0.00)$ & $\mathrm{P}(0.00)$ & $\mathrm{P}(0.02)$ & $\mathrm{P}(0.03)$ \\
\hline \multicolumn{2}{|c|}{ BARLEY } & \multicolumn{2}{|l|}{ MAIZE } & \multicolumn{2}{|c|}{ CASTORSEED } & \multicolumn{2}{|l|}{ CHANA } \\
\hline $\begin{array}{l}\text { DV: } \\
\text { future } \\
\text { price }\end{array}$ & $\begin{array}{l}\text { DV: spot } \\
\text { price }\end{array}$ & $\begin{array}{l}\text { DV: } \\
\text { spot } \\
\text { price }\end{array}$ & $\begin{array}{l}\text { DV: spot } \\
\text { price }\end{array}$ & $\begin{array}{l}\text { DV: future } \\
\text { price }\end{array}$ & $\begin{array}{l}\text { DV: spot } \\
\text { price }\end{array}$ & $\begin{array}{l}\text { DV: future } \\
\text { price }\end{array}$ & $\begin{array}{l}\text { DV: spot } \\
\text { price }\end{array}$ \\
\hline $\mathrm{P}(0.00)$ & $\mathrm{P}(0.00)$ & $\mathrm{P}(0.24)$ & $\begin{array}{l}\mathrm{P}(0.0004 \\
9)\end{array}$ & $\mathrm{P}(0.005)$ & $\mathrm{P}(0.0000)$ & $\mathrm{P}(0.00)$ & $\mathrm{P}(0.00)$ \\
\hline \multicolumn{2}{|l|}{ KAPAS } & \multicolumn{2}{|c|}{ POTATO AGRA } & & & & \\
\hline $\begin{array}{l}\text { DV: } \\
\text { future } \\
\text { price }\end{array}$ & $\begin{array}{l}\text { DV: } \\
\text { Spot } \\
\text { Price }\end{array}$ & $\begin{array}{l}\text { DV: } \\
\text { spot } \\
\text { price }\end{array}$ & $\begin{array}{l}\text { DV: } \\
\text { Spot } \\
\text { price }\end{array}$ & & & & \\
\hline $\mathrm{P}(0.00)$ & $\mathrm{P}(0.00)$ & $\mathrm{P}(0.00)$ & $\mathrm{P}(0.00)$ & & & & \\
\hline
\end{tabular}

The results show bi-directional Granger lead relationships between spot and futures in all the commodities except Turmeric.

In sum the results confirm that there is a price discovery process all the commodities except Turmeric .This makes futures market more informational efficient and cost competitive thus ensuring their lead role in price discovery.

\section{Summary Conclusions and Suggestions}

The literature relating to price discovery has mainly been confined to developed economies. Though commodity markets in emerging economies like India have been growing exponentially, commodities and commodity derivatives are neither popular asset classes, nor have they been adequately researched. Empirical Studies on the subject show that the introduction of derivatives contracts improves the liquidity and reduces informational 
asymmetries in the market. The present study evaluates price discovery in Indian commodities market to bridge the important gap in the literature.

We cover ten agricultural commodities and the study period is from June 2003-march 2011.We find that spot and futures prices of all sample commodities and indices are non stationary, and in fact integrated to order one except one commodity Turmeric in which null hypothesis is accepted and there is no cointegration revealed in this market. Long run equilibrium relationship is confirmed for 9 out of 10 commodities. The results of Granger causality test show bi-directional Granger lead relationships between spot and futures in all agricultural commodities except Turmeric in which there is no cointegration and causality and is not informationally efficient.

We conclude that Indian commodities market is still not perfectly competitive for some commodities. Overall, the price discovery results are encouraging given the nascent character of Indian commodity market. The commodity market in India needs strong policy support owing to its relevance in the macro economy with implications for price inflation, economic growth and employment. Hence there is an urgent need that the policy makers to support these trading platforms with infrastructure development, fiscal incentives, encouraging product innovation, widening investor base and investor education so that they are able to realise their true potential. Consequently, the institution of manager (or investor) should understand the futures markets clearly and supervise (or invest) properly to ensure the efficiency of futures market. More importantly, the international pricing authority in Indian futures market should be improved as quickly as possible in order to maintain economic security. The present research contributes to alternative investment literature for emerging markets. Future research on comparative analysis of emerging economies can grasp the true picture of improvements that are needed to capture the gains of derivative market in India which is outside the scope of present study.

\subsection{Policy Suggestions}

The policy suggestions include those relating to un-notice abrasions in market behaviour and measures that can strengthen the commodity futures trading in India.

$>$ The commodity exchanges must strengthen their surveillance system for early detection of anomalous trading behaviour especially the spot exchange so that they can also play a significant role in price discovery mechanism.

$>$ Given the above evidence these agri-commodities must be put under active monitoring on continuous basis.

$>$ The research findings are exchange-specific, as we have worked on data from NCDEX. Our findings have no implications for trading quality of other commodity exchanges. Futures and spot markets of all sample agri-commodities (with the exception of turmeric) exhibit price discovery process. The findings suggest that these markets are becoming informationally mature and market regulators have taken adequate steps for market development. 


\subsection{Measures for strengthening commodity futures market}

$>$ The government should pass the Forward Contract Regulation Amendment (FCRA) Bill 2010 at the earliest, which shall provide administrative and financial autonomy to Forwards Market Commission (FMC) and give it adequate powers to regulate commodity market and penalise any insider trading and price manipulations.

$>$ The Government must encourage futures trading in these markets as they play an important role in price discovery and price risk management. Suspension of trading is a not a solution and may actually harm the process of market development. Rather, an efficient surveillance system must be set in place, to minimize probability of price distortions.

$>$ Given the nascent nature of commodities derivatives market in India, the Government must support these trading platforms with by providing fiscal incentives, sound regulatory environment, infrastructure facilities and broad basing the investor list. Commodity market has economy wide implications on issues relating to inflation, infrastructure development, wealth creation, employment generation, etc. Hence, the Government support shall lead to market growth and overall economic development.

$>$ Well-organized spot markets must be developed, ensuring transparency and trading efficiency. Electronically traded spot exchanges must be developed and warehousing, testing labs as well as other eco-system linkages must be established.

$>$ Institutional investors' participation must be allowed so that these markets achieve higher trading liquidity. Innovative derivative instruments such as commodity options must be introduced to attract higher trading volumes and provide a better risk management alternative.

$>$ FMC must come out with a long term investor education strategy. Investor education is the best way to empower investors and hence the issue needs special attention. A well-informed investor's base shall create greater trading liquidity and help in avoiding price manipulations.

We have analysed price and trading data which was available with us. Intra-day information on prices, trading activity and different types of margin requirement especially in and around the event date would have helped us in getting even clearer picture. We recommend that a detailed analysis using high frequency data must be performed for a wide range of agri-commodities in order for the government and the market regulator to arrive at long-term policy conclusion and also to strengthen the spot market exchange also so that they can also play a very important role in price discovery mechanism and become more informationally efficient. 


\section{Macrothink}

International Journal of Accounting and Financial Reporting

ISSN 2162-3082 2012, Vol. 2, No. 2

\section{References}

Abhyankar, A. (1998). "Linear and Nonlinear Granger Causality: Evidence from the U.K. Stock Index Futures Market," Journal of Futures Markets, 18: 519-540.

http://dx.doi.org/10.1002/(SICI)1096-9934(199808)18:5<519::AID-FUT2>3.0.CO;2-U

Antoniou, A., Pescetto, G., and Violaris, A. (2001). "Modeling International Price Relationships and Interdependencies between EU Stock Index and Stock Index Futures Markets: A Multivariate Analysis," Working Paper, Centre for Empirical Research in Finance, Department of Economics and Finance, University of Durham.

Antoniou, A., and Garrett, I. (1993). "To What Extent did Stock Index Futures Contribute to the October 1987 Stock Market Crash?," Economic Journal, 103: 1444-1461.

http://dx.doi.org/10.2307/2234476

Antoniou, A. and Ergul, N. (1997). "Market Efficiency, Thin Trading and Non-linear Behavior: Evidence from an Emerging Market," European Financial Management, 3: 175-90. http://dx.doi.org/10.1111/1468-036X.00038

Bakaert, G. and Harvey, C.R. (1997). "Emerging Equity Market Volatility," Journal of Financial Economics, 43: 29-77.

http://dx.doi.org/10.1016/S0304-405X(96)00889-6

Bollerslev, T., Engle, R.F., Wooldridge, J.M., (1988), A Capital-asset pricing model with time varying covariances. Journal of Political Economy, vol. 96(1), pp.116-131.

http://dx.doi.org/10.1086/261527

B. B. Mandelbrot and J. Van Ness, Fractional Brownian motion, fractional noises and applications, SIAM Review, 10 (1968), pp. 422-437.

http://dx.doi.org/10.1137/1010093

Brooks, C., Rew, A.G., and Ritson, S. (2001). "A Trading Strategy based on the Lead-Lag Relationship between the Spot Index and Futures Contract for the FTSE 100," International Journal of Forecasting, 17: 31-44.

http://dx.doi.org/10.1016/S0169-2070(00)00062-5

Chan, K. (1992). "A Further Analysis of the Lead-Lag Relationship between the Cash Market and Stock Index Futures Market," Review of Financial Studies, 5: 123-152.

http://dx.doi.org/10.1093/rfs/5.1.123

Chan, K., Chan, K.C., and Karolyi, G.A. (1991). "Intraday Volatility in the Stock Index and Stock Index Futures Markets," Review of Financial Studies, 4: 657-684.

http://dx.doi.org/10.1093/rfs/4.4.657 


\section{Macrothink}

International Journal of Accounting and Financial Reporting

ISSN 2162-3082

2012, Vol. 2, No. 2

Cheung, Y.W., and Ng, L.K. (1990). "The Dynamics of S\&P 500 Index and S\&P 500 Futures Intraday Price Volatilities," Review of Futures Markets, 9: 458-486.

Chang, E., Jain, P., and Locke, P. (1995). "Standard \& Poor's 500 Index Futures Volatility and Price Changes around the New York Stock Exchange Close," Journal of Business, 68: 61-84. http://dx.doi.org/10.1086/296653

Dickey, D., Fuller, W., 1981. Likelihood ratio statistics for autoregressive time series with a unit root. Econometrica, vol. 49, pp. 1057-1072.

http://dx.doi.org/10.2307/1912517

Darrat, A. F., \& Rahman, S. (1995). Has futures trading activity caused stock price volatility?. Journal of Futures Markets, vol. 15, pp.537-557.

http://dx.doi.org/10.1002/fut.3990150503

Dey, K. and D. Maitra (2011): "Price Discovery and Market Efficiency Revisited: Anecdotes from the Indian Commodity Futures Markets". Commodity Vision, vol. 4(4), pp. 22-34.

Engle, R., (1982), Autoregressive conditional heteroscedasticity with estimates of the variance of UK inflation, Econometrica, Vol.50, pp. 987-1008.

http://dx.doi.org/10.2307/1912773

Engle, R.F., Ng, V.K., 1993. Measuring and testing the impact of news on volatility. Journal of Finance, vol. 48 (5), pp.1749-1778.

http://dx.doi.org/10.1111/j.1540-6261.1993.tb05127.x

Fu, L.Q. and Qing, Z.J. (2006), 'Price discovery and volatility spillovers: Evidence from Chinese spot-futures markets'.

Figlewski, Stephen (1981), "Futures trading and volatility in the GNMA market" Journal Of Finance.

http://dx.doi.org/10.1111/j.1540-6261.1981.tb00461.x

Fleming, J; Ostdiek, B and Whaley, R E (1996). "Trading Costs and the Relative Rates of Price Discovery in Stock, Futures, and Option Markets," Journal of Futures Markets,16(4), 353-87.

http://dx.doi.org/10.1002/(SICI)1096-9934(199606)16:4<353::AID-FUT1>3.0.CO;2-H

Floros, C. and Vougas, D.V. (2007). "Lead-Lag Relationship between Futures and Spot Markets in Greece: 1999 - 2001," International Research Journal of Finance and Economics, 7: 168-174.

Gardbade, K.D., and Silber, W.L. (1983). "Price Movements and Price Discovery in Futures 
and Cash Markets," Review of Economics and Statistics, 65: 289-297.

http://dx.doi.org/10.2307/1924495

Ghosh, Nilanjan (2009a). "Issues and Concerns of Commodity Derivative Markets in India: An Agenda for Research, Commodity Vision, vol. 3(4), pp.8-19.

Ghosh, Nilanjan (2009b). "Market Microstructure in the Indian Context", Commodity Vision, vol. 2(4), pp.10-17.

Ghosh, Nilanjan (2010a). "Role of Thin Commodity Futures Markets in Physical Market Price Making: An Analysis of Wheat Futures in India in the Post-Ban Era", Takshashila Academia of Economic Research (TAER), Working Paper No.6, pp.1-16.

Harris, L. (1989), 'S\&P 500 cash stock price volatilities', Journal of Finance, Vol. 144(5), pp. $1155-1175$.

Herbst, A., McCormack, J., and West, E. (1987). "Investigation of a Lead-Lag Relationship between Spot Indices and Their Futures Contracts," Journal of Futures Markets, 7: 373-381. http://dx.doi.org/10.1002/fut.3990070403

Hodgson, A., Masih, A.M.M., and Masih, R. (2006). "Futures Trading Volume as a Determinant of Prices in Different Momentum Phases," International Review of Financial Analysis, 15: 68-85.

http://dx.doi.org/10.1016/j.irfa.2004.10.014

Joel, H (2003), "Intraday Price Formation in U.S. Equity Index Markets," The Journal of Finance, 58(6), 2375-2399.

http://dx.doi.org/10.1046/j.1540-6261.2003.00609.x

Johansen, S.J. (1991), 'Estimation and hypothesis testing of cointegration vectors in Gaussian vectors auto regression models, Econometrica, vol. 59, pp. 1551-80.

http://dx.doi.org/10.2307/2938278

Kavussanos, M. and I.D. Visvikis (2004), 'Market interactions in returns and volatilities between spot and forward shipping markets', Journal of Banking and Finance, 2004.

Kavussanos M.G., Visvikis, I.G., and Alexakis, P.D. (2008). "The Lead-Lag Relationship between Cash and Stock Index Futures in a New Market," European Financial Management, 14: $1007-1025$

http://dx.doi.org/10.1111/j.1468-036X.2007.00412.x

Kawaller, I.G., Koch, P.D., and Koch, T.W. (1987). "The Temporal Price Relationship between S\&P 500 Futures and the S\&P 500 Index," Journal of Finance, 42: 1309-1329. 


\section{Macrothink}

http://dx.doi.org/10.1111/j.1540-6261.1987.tb04368.x

Garbade, K.D., and Silber, W.L. (1983), 'Dominant satellite relationship between live cattle cash and futures markets', The Journal of Futures Markets, vol. 10(2), pp. 123-136.

Glosten, L. R.; R. Jagannathan and D. E. Runkle, 1993. On the relationship between the expected value and the volatility of the nominal excess return on stocks, Journal of Finance, vol. 48 (5), pp.1779-1801.

http://dx.doi.org/10.1111/j.1540-6261.1993.tb05128.x

Greene W H. 1997. Econometric analysis (3rd edition). Engelwood Cliffs, NJ: Prentice Hall.

Krishnan, R., (2009), Risk measurement and modeling risk-I, presented at Quantitative Finance Workshop, Indira Gandhi Institute of Development Research Institute, December 17-20, Mumbai, India.

Kumar, S and Sunil, B. (2004), 'Price discovery and market efficiency: evidence from agricultural future commodities', South Asian Journal of Management, April 1.

Kumar and Pandey (2011), "International Linkages of the Indian Commodity Futures $\begin{array}{llll}\text { Markets", viewed } & \text { on } & 10 & \text { May, }\end{array}$ (http://campus-for-finance.com/filebrowser/files/Papers/49a40606787_name.pdf dated 15.03.2011).

Kabra, K. N. (2007). "Commodity Futures in India". Economic and Political Weekly, vol. 42 (31), pp.1163- 1169.

Koutmos, G. and G. Booth, 1995. Asymmetric volatility transmission in international stock markets, Journal of International Money and Finance, vol. 14, pp. 747-762.

http://dx.doi.org/10.1016/0261-5606(95)00031-3

Koontz, S.R., P. Gracica and Hudson, M.A. (1990), 'Estimation and hypothesis testing of cointegration vectors in Gaussian Vector Autoregressive Models', Econometrica 59, P: 1551-1580.

Koutmos, G. and M. Tucker, 1996. Temporal relationships and dynamic interactions between spot and futures stock markets, Journal of Futures Markets, vol. 16, pp. 55-69. http://dx.doi.org/10.1002/(SICI)1096-9934(199602)16:1<55::AID-FUT3>3.0.CO;2-G

Lien, D. and Tse, Y.K. (2000), 'Some recent development in futures hedging', Working Paper University of Texas at San Antonio.

Moosa, I.A. (2002), 'Price discovery and risk transfer in the crude oil futures markets: some 
structural time series evidence', Benna Monte del Paschi de Sienna Spa, Vol.31, Blackwell Publishers.

Mandelbrot, B.B. (1963), "The Variation of Certain Speculative Prices," Journal of Business, vol. 36, pp.394-419.

http://dx.doi.org/10.1086/294632

Nelson, D., 1991.Conditional Heteroscedasticity in Asset Returns: A New Approach. Econometrica, vol. 59, pp.347-370.

http://dx.doi.org/10.2307/2938260

Naik, Gopal and S.K. Jain (2002), "Indian Agricultural Commodity Futures Market". Economic and Political Weekly, vol. 37(30), pp. 3161-3173.

Phillips, P.C.B., Perron, P., 1988. Testing for a unit root in time series regressions. Biometrica, vol. 75, pp.335-346.

http://dx.doi.org/10.1093/biomet/75.2.335

Pericli and Koutmos, 1997, "Index futures and options and stock market volatility", Journal of Futures Markets, vol. 17, pp. 957-974.

http://dx.doi.org/10.1002/(SICI)1096-9934(199712)17:8<957::AID-FUT6>3.0.CO;2-K

Schroeder, T.C., and Goodwin, B.K. (1991). "Price Discovery and Cointegration for Live Hogs," Journal of Futures Markets, 11: 685-696.

http://dx.doi.org/10.1002/fut.3990110604

Stoll, H.R., and Whaley, R.E. (1990). "The Dynamics of Stock Index and Stock Index Futures Returns," Journal of Financial and Quantitative Analysis, 25: 441-468.

http://dx.doi.org/10.2307/2331010

Tan, H B and Lim, C S (2001). "Intraday Price Discovery in the Malaysian Stock Index Futures and Cash Markets," Banker's Journal Malaysia, 4(1), 117-130.

Tomek, W.G. (1980). "Price Behavior on a Declining Terminal Market," American Journal of Agricultural Economics, 62: 434-445.

http://dx.doi.org/10.2307/1240198

Thomas, S and Karande, K. (2001), 'Price discovery across multiple spot and futures markets', 'IGIDR, Mumbai, http//www.igidr.ac.in 23. • Roy, A. (2008): "Dynamics of Spot and Future Markets in Indian Wheat Market: Issues and Implications", Indian Institute of Management, Ahmedabad, viewed on 20 March 2011 (http://ssrn.com/abstract==1178762).

Roy, S. and K. Dey (2009), "Current Status of Derivative Products in India: An Overview", 


\section{Macrothink \\ International Journal of Accounting and Financial Reporting \\ ISSN 2162-3082 2012, Vol. 2, No. 2}

Teaching note, Institute of Rural Management, Anand, pp. 1-12.

J. Yang, R. B. Balyeat and D. J. Leatham, (2005), "Futures Trading Activity and Commodity Cash Price Volatility," Journal of Business Finance and Accounting, Vol. 32(1-2), pp. 297-323. doi:10.1111/j.0306-686X.2005.00595.x http://dx.doi.org/10.1111/j.0306-686X.2005.00595.x

Zhong, M., Darrat, A.F., and Otero, R. (2004), 'Price discovery and volatility spillovers in index futures markets: some evidence from Mexico', Journal of Banking and Finance, vol. 28, pp. 3037-3054.

http://dx.doi.org/10.1016/j.jbankfin.2004.05.001

Zapata, H., Fortenbery, T.R. and Armstrong, D. (2005)', 'Price discovery in the world sugar futures and cash markets: implications for the Dominican Republic', Staff Working Paper No.469, March, Agricultural and Applied Economics.

\section{Biography}

Prof Sanjay Sehgal, University of Delhi - Sanjay Sehgal is Ph.D. finance from Delhi School of Economics and post doctoral commonwealth research fellow from London School of Economics, UK. He is professor of Finance at Department of Financial Studies, South Campus, and University of Delhi, India, sanjayfin15@gmail.com.

Dr. Namita Rajput, University of Delhi - Namita Rajput has a $\mathrm{PhD}$ in International Business from the Faculty of Commerce and Business and Post Doctoral from Department of Financial Studies, University of Delhi. Presently she is an Associate Professor in the Department of Commerce at Sri Aurobindo College (M) India. namitarajput27@gmail.com 